\title{
Occurrence of Harmonia axyridis (Coleoptera: Coccinellidae) in field crops
}

\author{
Axel VANDEREYCKEN ${ }^{1}$, Yves BROSTAUX ${ }^{2}$, Emilie JOIE ${ }^{1}$, ERic HAUBRUGE ${ }^{1}$ and François J. VERHEGGEN ${ }^{1}$ \\ ${ }^{1}$ University of Liege, Gembloux Agro-Bio Tech, Entomologie fonctionnelle et évolutive; Passage des Déportés 2, B-5030 \\ Gembloux, Belgium; e-mails: a.vandereycken@ulg.ac.be; ejoie@ulg.ac.be; e.haubruge@ulg.ac.be; fverheggen@ulg.ac.be \\ ${ }^{2}$ University of Liege, Gembloux Agro-Bio Tech, Unité de Statistique, Informatique et Mathématique appliquées, Avenue de la \\ Faculté 8, B-5030 Gembloux, Belgium; e-mail: y.brostaux@ulg.ac.be
}

Key words. Coleoptera, Coccinellidae, Harmonia axyridis, habitat, crops, agroecosystems, ladybird, exotic species

\begin{abstract}
The Multicoloured Asian Ladybird, Harmonia axyridis Pallas (Coleoptera: Coccinellidae) is known to thrive principally in shrubby and arboreal habitats. This study focuses on the occurrence of this exotic species and its seasonal abundance in various field crops. The abundance of adults, larvae and pupae of H. axyridis was evaluated over a three-year period, from 2009 to 2011 , in four important agronomical crops (wheat, corn, broad bean and potato) in Belgium. From May to September, $481-\mathrm{m}^{2}$ quadrats were visually inspected in each of the fields sampled on several farms every seven days. H. axyridis colonized and reproduced in all of the four crops studied, with the largest numbers recorded in corn and broad bean crops. Larvae and adults of $H$. axyridis were recorded mainly in corn and to a much less extent in wheat and potato crops. From 2009 to 2011, the mean weekly abundance of $H$. ayxridis remained constant except in corn crops, where the recorded densities of all the immature stages and adults were higher in 2011 than in 2009. The population dynamics of aphids and H. axyridis are well described by a symmetric logistic function (S-shape) of cumulative population size. H. axyridis was not always recorded where aphids were abundant, e.g. aphids were abundant on wheat where no $H$. axyridis were recorded. $H$. axyridis start reproducing after the peak in aphid population, suggesting that $H$. axyridis is able to complete its development by feeding on alternative prey such as larvae and pupae of the same and other species of ladybird and other aphidophagous species. H. axyridis is often considered to be bivoltine but it only completes one generation per year in field crops. The second generation generally develops late in the season in other habitats.
\end{abstract}

\section{INTRODUCTION}

At the end of the 20th century, the Multicoloured Asian ladybird Harmonia axyridis Pallas (Coleoptera: Coccinellidae), a native species of Asia, was introduced into North America and Europe as a biological control agent of aphids and coccids (Adriaens et al., 2008; Brown et al., 2008a, 2011) because its larvae are both voracious and polyphagous (Ferran \& Dixon, 1993). It has successfully invaded 26 European, nine American and three African countries (Brown et al., 2011). In Belgium, H. axyridis was first observed in field crops (potatoes) in 2003 (Jansen \& Warnier, 2004). H. axyridis is often considered to be semi-arboreal (Hodek, 1973) but it has become ubiquitous in many parts of the world including America, Europe and Africa (Brown et al., 2011) where it occurs in agricultural areas (Colunga-Garcia \& Gage, 1998; Lucas et al., 2007), riparian zones (Adriaens et al., 2008) and orchards (Michaud, 2002; Burgio et al., 2008).

$H$. axyridis has been introduced as a biological control agent of various pests on crops such as pecan (Tedders \& Schaefer, 1994), red pine (McClure, 1987), apple (Brown \& Miller, 1998), soybeans, sweet corn (Musser \& Shelton, 2003), alfalfa (Buntin \& Bouton, 1997; ColungaGarcia \& Gage, 1998), cotton (Wells et al., 2001), tobacco (Wells \& McPherson, 1999) and winter wheat (Colunga-Garcia \& Gage, 1998). Its great dispersal ability has enabled it to rapidly colonize large areas (Tedders \& Schaefer, 1994; Koch, 2003).
In Belgium, $H$. axyridis is one of the five most abundant aphidophagous species in field crops such as corn, wheat, potato and broad bean. There is relatively little information on its phenology as it has only been studied in a few field crops in Belgium, e.g. potato (Jansen \& Hautier, 2008), green pea and wheat, and in stands of stinging nettle (Alhmedi et al., 2009).

$H$. axyridis has the ability to colonize new habitats and is a very competitive species, being frequently reported as a predator of native species (Phoofolo \& Obrycki, 1998; Sloggett et al., 2009; Wells et al., 2010; Ingels \& De Clercq, 2011). With the increase in the abundance of $H$. axyridis there have been reports of a decline in the abundance of native aphidophagous ladybirds (Adalia bipunctata Linné) (Ottart, 2005; Roy et al., 2012).

Predators and prey species are naturally synchronised (Tenhumberg \& Poehling, 1995) but field observations indicate that $H$. axyridis arrive later than other ladybirds and the peak in the number of its larvae occurs after the aphid peak (Jansen \& Hautier, 2008).

There are many European (Adriaens et al., 2008) and American (Colunga-Garcia \& Gage, 1998) studies on the ecology of $H$. axyridis, but its colonization of field crops is poorly understood. In this study, we quantified and compared the abundance of $H$. axyridis in four important crops: wheat, corn, potato and broad bean, over a period of three-years. We further studied the changes in abundance of each developmental stage during one year in the different habitats. A phenological model was used to 
TABLE 1. Logistic and Gompertz equations with their parameters (see text for explanation of parameters M, a and b).

\begin{tabular}{|c|c|c|c|c|c|c|}
\hline \multirow{2}{*}{ Model } & \multirow{2}{*}{ Equation } & \multicolumn{2}{|c|}{ Growth rate } & \multicolumn{2}{|c|}{ Coordinate of inflection point } & \multirow{2}{*}{$\mathrm{T}$} \\
\hline & & Max & Mean & $\mathrm{x}$ & $\mathrm{y}$ & \\
\hline Logistic & $y=\frac{M}{1+e^{-\left(\frac{x-a}{b}\right)}}$ & $\frac{M}{4 b}$ & $\frac{M}{6 b}$ & $\mathrm{a}$ & $\frac{M}{2}$ & $6 \mathrm{~b}$ \\
\hline Gompertz & $y=M e^{-e^{-\left(\frac{x-a}{b}\right)}}$ & $\frac{M}{e b}$ & $\frac{M}{4 b}$ & $\mathrm{a}$ & $\frac{M}{e}$ & $4 \mathrm{~b}$ \\
\hline
\end{tabular}

describe population growth in the year 2011. Finally, we discuss the potential effect of $H$. axyridis on native species during periods when food is scarce.

\section{MATERIAL AND METHODS}

\section{Field crops sampled and sampling method}

Populations of $H$. axyridis were sampled from 2009 to 2011 in a Belgian agricultural production area called Hesbaye. In this area, nine fields of four crops were chosen for their agronomic importance: wheat Triticum aestivum (L.); corn Zea mays (L.); potato Solanum tuberosum; (L.) and broad bean Vicia faba (L.). All crop fields received conventional treatments to control pests. The sampling period for wheat and broad bean was from mid-May to late August, and for corn and potato from mid-May to late September.

The method used to monitor and assess the numbers of predators and aphids consisted of visual whole-plant inspections of the plants in $481-\mathrm{m}^{2}$ quadrats per crop. The number of quadrats sampled in a field was a function of the area of the field. The quadrats were distributed randomly throughout the fields. In order to avoid the influence of other nearby crops quadrats were not placed within $20 \mathrm{~m}$ of the border of each field. All quadrats were examined every week. Visual sampling was conducted as it provides an easy and accurate method of estimating the numbers of larvae and adults of coccinellids in field crops (Michels \& Behle, 1992). Quadrats were located along transect lines across each field and spaced $20 \mathrm{~m}$ apart. All leaves and stems within the quadrat were examined and all aphids and aphidophagous insects were recorded. Eggs were counted individually rather than per clutch. Eggs, first instar larvae and pupae were brought back in order to let them develop under laboratory conditions $\left(\mathrm{T}=24 \pm 1{ }^{\circ} \mathrm{C}\right.$; $\left.\mathrm{HR}=75 \pm 5 \%\right)$ for identification to species level. Aphid species were also determined and their population densities evaluated: aphids were counted on all leaves and stems at the same time as the aphidophagous insects were sampled.

\section{Statistical analyses}

The mean numbers of $H$. axyridis per crop and per period of observation were calculated per quadrat. As mean densities recorded per $1 \mathrm{~m}^{2}$ were low, values per $100 \mathrm{~m}^{2}$ are presented. This mean number was also determined within each crop for each season, and analysed using an Analysis of Variance (ANOVA) with crop $(\mathrm{q}=4)$ and years $(\mathrm{n}=3)$ as factors $(\alpha=0.05)$. Mean numbers of aphid predators were compared by Least Square Differences (LSD). To explain variations in predator abundances, the mean abundance per species was then analysed using Analysis of Covariance (ANCOVA: General Linear Models) with years $(\mathrm{n}=3)$ as factors $(\alpha=0.05)$ and aphid densities as a co-variable. The distribution of data (counting) was asymmetric and had to be $\log _{10}(x+1)$ transformed before analysis. Although statistical analyses were performed on the transformed data, the untransformed data are presented in Figs 1-5. Statistical analyses were carried out using Minitab ${ }^{\circledR}$ 15.1.30.0 (State College, PA, USA).

\section{Phenological model}

Prey and predator species specialized in the exploitation of ephemeral resources can be modelled using Pearl-Verhulst models (Matis et al., 2009). From this model, logistic and Gompertz curves are commonly used to describe phenology and population growth in fish, birds and mammals (López et al., 2000; Darmani Kuhi et al., 2003; Phoofolo et al., 2009). The phenological observations are distributed following roughly bell-shaped curves. Instead of adjusting these models, we chose to work with cumulative population sizes and then integrated distributional functions, which are easier and more robust to fit. The resulting sigmoid functions (S-shapes) provide population parameters corresponding to charateristic phenological points, e.g. the inflection point, which gives the maximum specific population peak (Debouche, 1979). The parameters permit a description and comparison over time of population phenology.

For 2011, we described the $H$. axyridis and aphid cumulative population sizes using logistic and Gompertz growth curves (Debouche, 1979). These two equations are composed of three mathematical constants: M, maximum densities; a, abscise of the inflection point; and $b$, measure of population spread (Table 1). The choice of the best adjusted model was based on the lowest residual sum of square (RSS) (e.g. Zwietering et al., 1990). Factors used to compare growth trajectories are coordinates: cumulative temperature (Temperatures were measured each hour and a mean daily temperature was calculated. The cumulative temperature is the sum of these daily temperatures.); cumulative densities, values of maximum growth rate (Vmax) and mean growth rate $(\mathrm{Vm})$ and time (T) (Winsor, 1932). The temperatures were first recorded on May 17th, 2011.

\section{RESULTS}

\section{Population changes and habitat preferences}

Very few individuals of $H$. axyridis were recorded in wheat and potato, but some larvae were recorded indicating that reproduction occurred in these crops (Figs 1 and 2). However, there are too few data to support statis-

TABLE 2. Summary of the results of the ANOVA of the density of $H$. axyridis recorded in corn and broad bean crops over a period of three years $(2009,2010$ and 2011). The Crop column records the crop where $H$. axyridis was the most abundant $(\mathrm{C}-$ corn). ( $\mathrm{P}$ values obtained using the GLM ns: $\mathrm{P}>0.05, * \mathrm{P}<$ $0.05, * * * \mathrm{P}<0.001)$.

\begin{tabular}{ccccc}
\hline & Year & $\mathrm{F}$ & $\mathrm{P}$ & Crops \\
\hline \multirow{4}{*}{ Larvae } & 2009 & $1.43(1,245)$ & $\mathrm{ns}$ & \\
& 2010 & $4.43(1,1168)$ & $*$ & $\mathrm{C}$ \\
& 2011 & $44.54(1,1307)$ & $* *$ & $\mathrm{C}$ \\
\hline \multirow{4}{*}{ Adults } & 2009 & $0.11(1,245)$ & $\mathrm{ns}$ & \\
& 2010 & $0.15(1,1168)$ & $\mathrm{ns}$ & \\
& 2011 & $16.74(1,1307)$ & $* * *$ & $\mathrm{C}$ \\
\hline
\end{tabular}




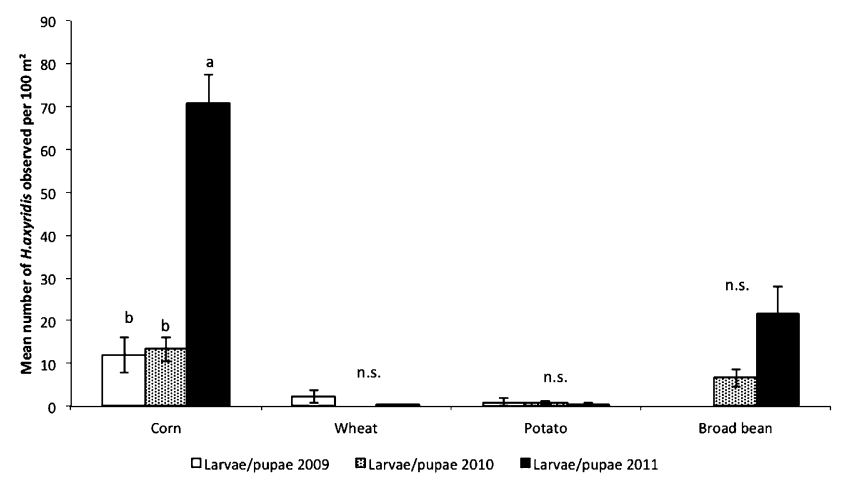

Fig. 1. Mean number $( \pm \mathrm{SE})$ of $H$. axyridis larvae recorded in corn, wheat, potato and broad bean crops in 2009, 2010 and 2011. Means for a crop followed by the same letter do not differ significantly, $\mathrm{P}>0.05$, LSD test; n.s. $=$ not significant.

tical analyses such as ANOVA and LSD. Corn and broad bean were the two crops with the most $H$. axyridis. Over the three years of the study more larvae of $H$. axyridis were recorded on broad bean than corn (Table 2). In 2009 , no H. axyridis were recorded on broad bean $\left(\mathrm{t}_{217}=\right.$ $2.85 ; \mathrm{p}$-value $=0.0024)$. In corn crops, the numbers of larvae varied significantly from 2009 to $2011\left(F_{2,1709}=\right.$ $39.99, P<0.001)$ with an increase in $2011(70.8 \pm 6.6$ larvae per $\left.100 \mathrm{~m}^{2}\right)$ compared to $2010(13.3 \pm 2.8$ larvae per $\left.100 \mathrm{~m}^{2}\right)(\mathrm{P}<0.05$; LSD) (Fig. 1). Similarly in 2011 there were more adults in corn than broad bean crops (Table 2). The density in 2011 was $19.98 \pm 1.80$ individuals per $100 \mathrm{~m}^{2}$, which is significantly higher than the $7.8 \pm 2.0$ and $3.9 \pm 0.9$, respectively, recorded in 2009 and $2010\left(F_{2,1709}=14.53, P<0.001\right)($ Fig. 2$)$.

The ANCOVA analyses highlighted two things: (1) a linear relationship between abundance of aphids and number of adults of $H$. axyridis recorded on corn $\left(\mathrm{P}_{\text {aphids }}<\right.$ 0.05 , ANCOVA) and (2) annual changes in the abundance of larvae $\left(F_{2,1708}=41.24 ; P_{\text {Years } a p h i d s}<0.001\right)$ and adult predators on corn $\left(F_{2,1708}=15.36 ; P_{\text {Years } / \text { aphids }}<\right.$ 0.001 ). The linear relation between the abundance of aphids and $H$. axyridis indicates that on average the higher the abundance of aphids the more $H$. axyridis are

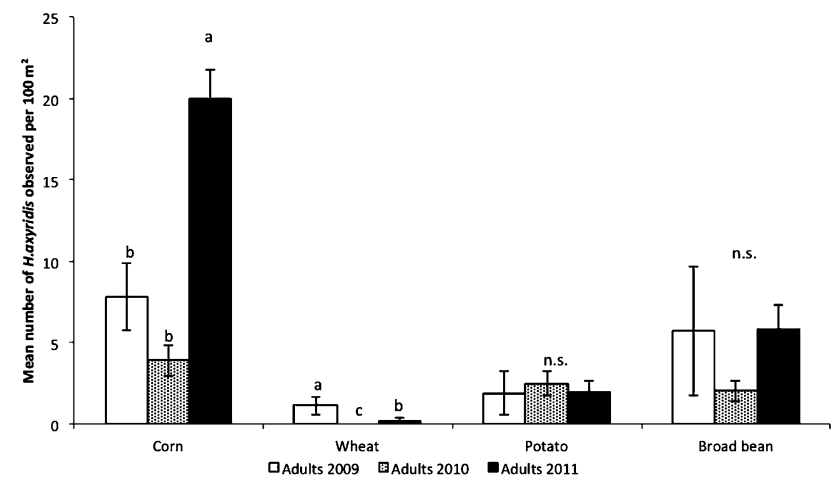

Fig. 2. Mean number ( $\pm \mathrm{SE})$ of adult $H$. axyridis recorded in corn, wheat, potato and broad bean crops in 2009, 2010 and 2011. Means for a crop followed by the same letter do not differ significantly, $\mathrm{P}>0.05$, LSD test; n.s. $=$ not significant.

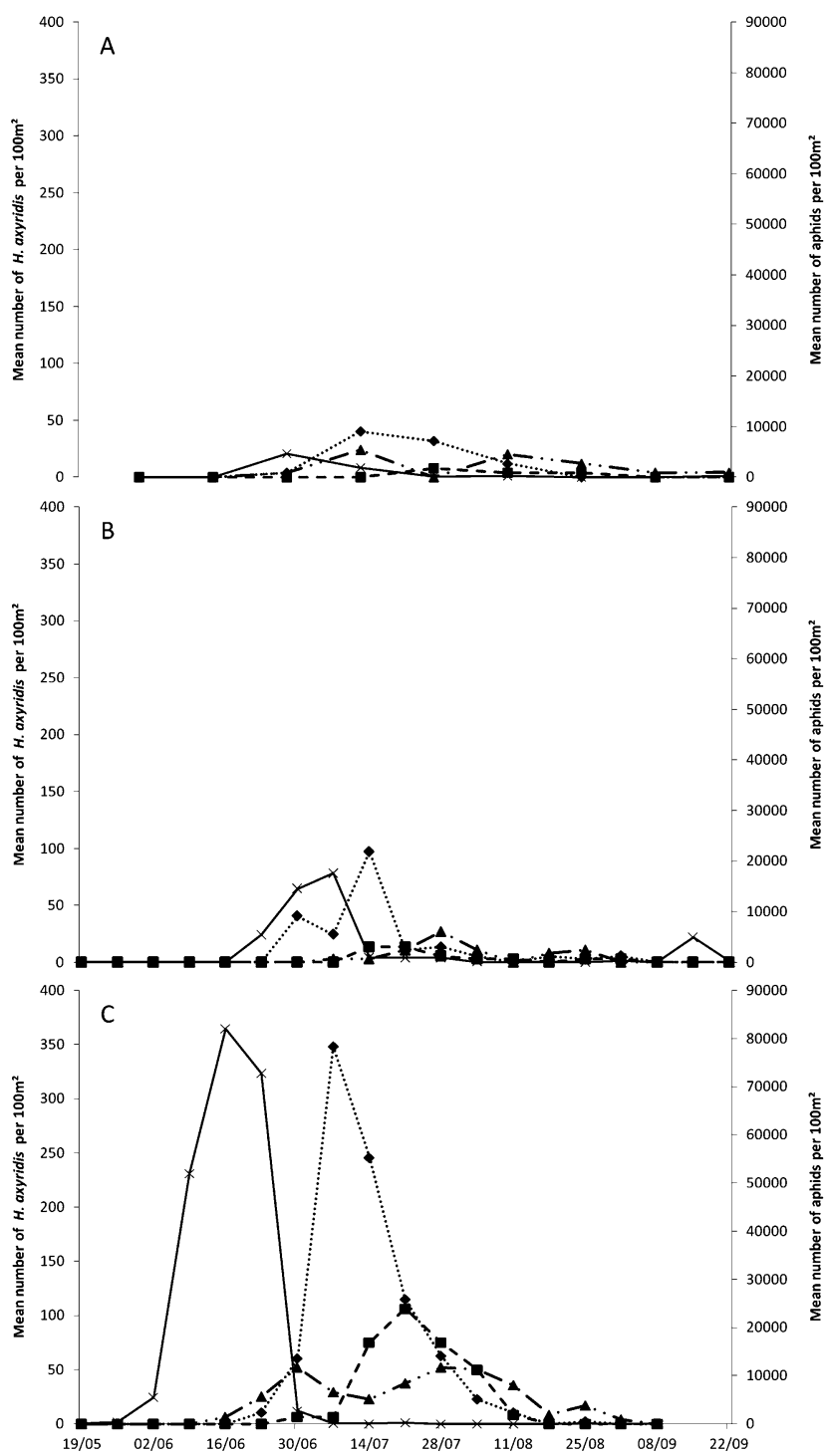

Fig. 3. Trends in time in the numbers of $H$. axyridis recorded in corn crops in 2009 (A), 2010 (B) and 2011 (C) (grey plain line - aphids, dotted - larvae, dashed - pupae, dotted/dashed adults).

recorded. The exact relation can be more complex, with for example a shift or a nonlinear tendency.

\section{Phenology}

The phenology of $H$. axyridis was studied only in corn (Fig. 3) and broad bean crops (Fig. 4), where sufficient numbers of this ladybird were recorded (with densities higher than 5 individuals per $100 \mathrm{~m}^{2}$ ).

In corn, depending on the year, adults appeared between mid-June and early July and there were two peaks in abundance, the first in July and the second in August. Adults were recorded up to the end of August in 2010 and 2011 and mid-September in 2009. Larvae were recorded from end of June to early September, except in 2009 when no larvae were recorded after mid-August. There was one peak in the numbers of larvae, which was recorded each year at the beginning of July. Depending 


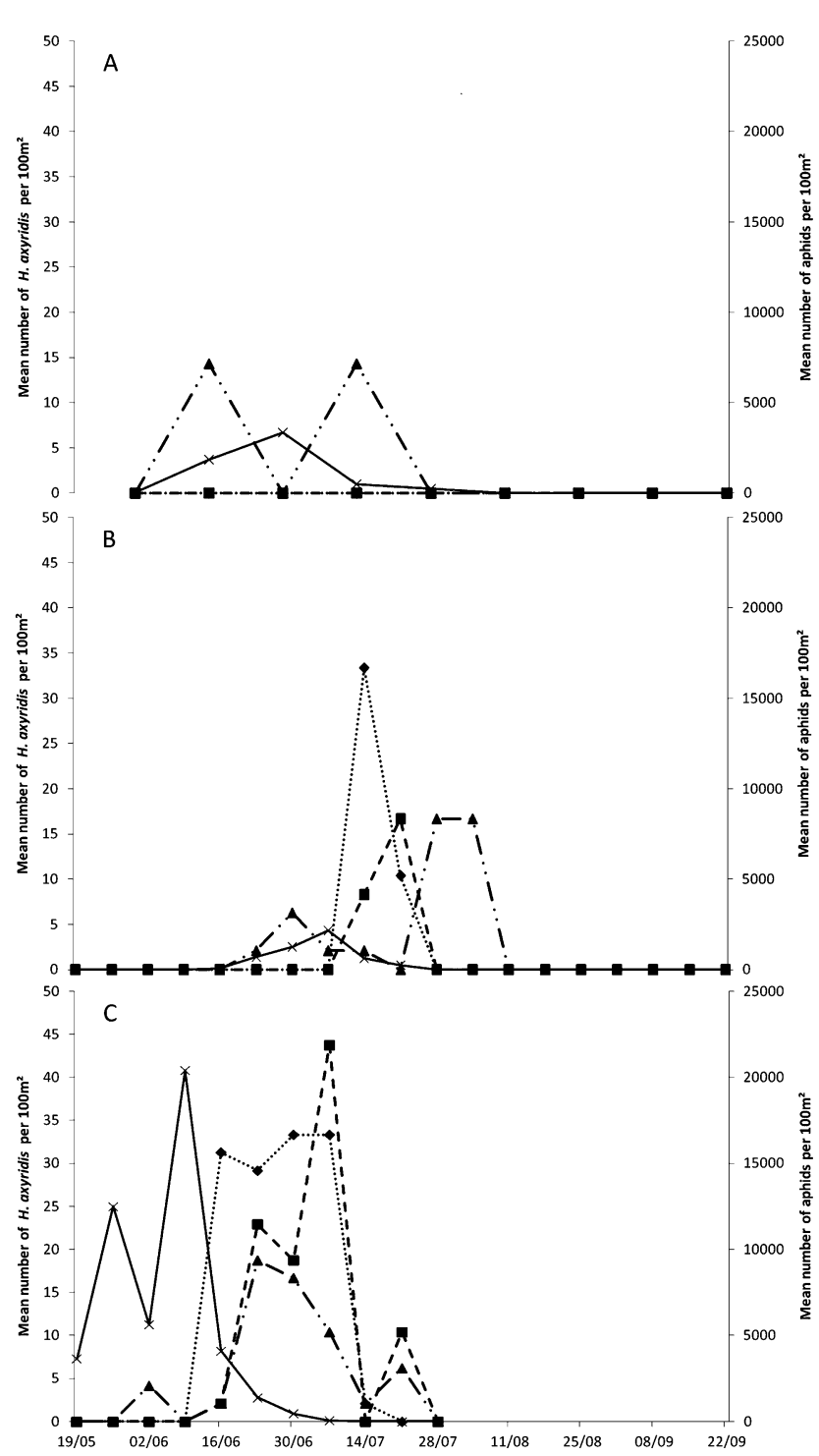

Fig. 4. Trends in time in the numbers of $H$. axyridis recorded in broad bean crops in 2009 (A), 2010 (B) and 2011 (C) (grey plain line - aphids, dotted - larvae, dashed - pupae, dotted/dashed - adults).

on the year, adult emergence occurred from mid-August until early September.

In broad bean crops, adults were recorded between June 1 and June 23, depending on the year (Fig. 4). There were two peaks in the numbers of adults, the first at the end of June and second at the end of July. Larvae were recorded in mid-June in 2011 (Fig. 4C) and mid-July in 2010 (Fig.

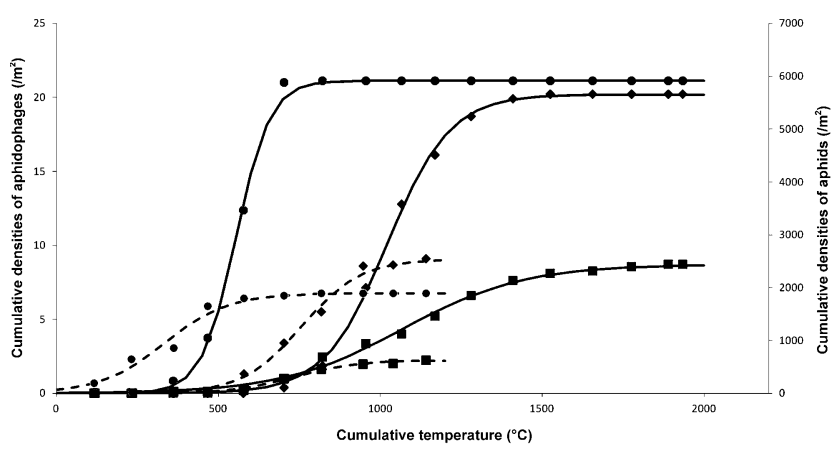

Fig. 5. Relationships between cumulative temperature $\left({ }^{\circ} \mathrm{C}\right)$ and cumulative abundance of larvae and adults of $H$. axyridis and aphids recorded in broad bean and corn crops. (line - corn, dote - broad bean, circles - aphids, squares $-H$. axyridis adult, diamonds $-H$. axyridis larvae).

4B). The larvae were recorded over a period of two weeks in 2010 and five weeks in 2011.

Aphids were recorded earlier on corn in $2011\left(18^{\text {th }}\right.$ May) (Fig. 3C) than 2009 (27th June) (Fig. 3A) and 2010 (16th June) (Fig. 3B). There was a decrease in aphid numbers and an increase in the numbers of larvae at the end of June. Similar trends were recorded on broad bean crops but aphids were recorded earlier on beans in 2011 (before $19^{\text {th }}$ May) (Fig. 4C). The numbers of aphids started to decrease in June before $H$. axyridis started reproducing (Fig. 4B, C).

\section{Phenological model}

The change in the numbers of both aphids and predators on broad bean and corn was linked to cumulative temperature. Two models (logistic and Gompertz) were compared using the values of their residual sum of squares (RSS). Both of these models fit the data well as their RSSs are low. Nevertheless, we decided to use the logistic model to analyze the growth trajectory because it has the lowest RSS for the aphid and predator data (Table $3)$. The logistic curves are sigmoidal in shape and the inflection point occurs earlier in the data recorded for aphids, larvae and adults of $H$. axyridis on broad bean than on corn (Table 4 and Fig. 5). This reflects the earlier development of both prey and predator on broad bean than on corn. The peak larval populations were recorded at 426 and 466 degree-days after those of aphids on broad bean and corn, respectively. The peak larval population growth rate recorded on corn was 0.052 and twice the 0.025 predators $/ \mathrm{m}^{2} /$ degree-day recorded on broad bean. The length of larval activities was similar in the two cul-

TABLE 3. Fit and RSS values of the phenological model of $H$. axyridis abundance recorded in broad bean and corn crops.

\begin{tabular}{|c|c|c|c|c|}
\hline & \multicolumn{2}{|c|}{ Larvae } & \multicolumn{2}{|c|}{ Adults } \\
\hline & Gompertz & Logistic & Gompertz & Logistic \\
\hline $\begin{array}{c}\text { Broad } \\
\text { bean }\end{array}$ & $\begin{array}{c}y=9.08 e^{-e^{-\left(\frac{x-693.77}{132.72}\right)}} \\
\text { RSS: } 1.39\end{array}$ & $\begin{array}{c}y=\frac{9.08}{1+e^{-\left(\frac{x-758.47}{90.51}\right)}} \\
\text { RSS: } 0.76\end{array}$ & $\begin{array}{c}y=2.23 e^{-e^{-\left(\frac{x-679.16}{128.38}\right)}} \\
\text { RSS: } 0.05\end{array}$ & $\begin{array}{c}y=\frac{2.23}{1+e^{-\left(\frac{x-736.44}{93.42}\right)}} \\
\text { RSS: } 0.06\end{array}$ \\
\hline Corn & $\begin{array}{c}y=20.20 e^{-e^{-\left(\frac{x-957.19}{138.23}\right)}} \\
\text { RSS: } 0.83\end{array}$ & $\begin{array}{c}y=\frac{20.20}{1+e^{-\left(\frac{x-1020.98}{97.07}\right)}} \\
\text { RSS: } 0.93\end{array}$ & $\begin{array}{c}y=8.71 e^{-e^{-\left(\frac{x-938.03}{274.95}\right)}} \\
\text { RSS: } 1.46\end{array}$ & $\begin{array}{c}y=\frac{8.71}{1+e^{-\left(\frac{x-1069.60}{187.40}\right)}} \\
\text { RSS: } 1.06\end{array}$ \\
\hline
\end{tabular}


TABLE 4. The phenological factors determining the trajectories of H. axyridis and aphid abundance recorded in broad bean and corn crops.

\begin{tabular}{|c|c|c|c|c|c|c|}
\hline & \multicolumn{3}{|c|}{ Broad bean } & \multicolumn{3}{|c|}{ Corn } \\
\hline & Larvae & Adults & Aphids & Larvae & Adults & Aphids \\
\hline Function & Logistique & Logistique & Logistique & Logistique & Logistique & Logisitque \\
\hline $\mathrm{a}$ & 758,47 & 736,44 & 332,62 & 1020,98 & 1069,60 & 554,90 \\
\hline $\mathrm{b}$ & 90,51 & 93,42 & 100,29 & 97,07 & 187,40 & 52,72 \\
\hline M & 9,08 & 2,23 & 1895,21 & 20,20 & 8,71 & 5917,17 \\
\hline Vmax coordinates & $(758.47,4.54)$ & $(736.44,1.12)$ & $(332.62,947.61)$ & $(1020.9,10.1)$ & $(1069.6,4.35)$ & $(554.89,2958.58)$ \\
\hline Vmax (aphidophages $/ \mathrm{m}^{2}$ ) & 0,025 & 0,006 & 4,724 & 0,052 & 0,012 & 28,059 \\
\hline Vm (aphidophages $/ \mathrm{m}^{2}$ ) & 0,017 & 0,004 & 3,150 & 0,035 & 0,008 & 18,706 \\
\hline T (degree-day) & 543,06 & 560,52 & 601,74 & 582,40 & 1124,40 & 316,33 \\
\hline
\end{tabular}

tures despite differences in length of aphid activities, which were two times higher in broad bean than in corn (Table 4).

\section{DISCUSSION}

Over a period of three years the numbers of $H$. axyridis in four crops (broad bean, corn, wheat and potato) were recorded in the southern part of Belgium. Our data show that this exotic ladybird regularly occurs in these field crops. Previous studies on $H$. axyridis indicate that this species is more frequently found in urban and arboreal habitats $(65.6 \%)$ than on herbaceous plants $(34.4 \%)$ (LaMana \& Miller, 1996; Adriaens et al., 2008). In addition to arboreal habitats, it is also recorded in field crops such as wheat, corn and potato (LaMana \& Miller, 1996; Buntin \& Bouton, 1997; Colunga-Garcia \& Gage, 1998; Michaud, 2002; Brown, 2003; Nault \& Kennedy, 2003; Snyder et al., 2004; Jansen \& Hautier, 2008), and also in various natural or semi-natural herbaceous habitats, such as nettle beds, clover or peppermint (LaMana \& Miller, 1996; Koch et al., 2006; Alhmedi et al., 2007).

$H$. axyridis larvae and adults were recorded in all of the four crops sampled but were less prevalent in potato and wheat crops, where less than one individual per $100 \mathrm{~m}^{2}$ were recorded. Their reproduction in these two crops was limited and did not vary during the three years of this study. Other studies have shown that they tend to reproduce where aphids are abundant (Evans \& Gunther, 2005; Jansen \& Hautier, 2008). However, even when aphids were present in significant numbers on wheat, we recorded very few $H$. axyridis. The use of insecticides to control aphid populations on wheat is unlikely to be the cause of the low numbers of $H$. axyridis because after the insecticide application there were many individuals of other species. It is likely that the abiotic conditions in wheat, associated with high plant density (low brightness, high humidity), are not suitable for $H$. axyridis. The numbers of $H$. axyridis recorded on potato were also low, which was possibly due to the low availability of food on potato and some of the plant's characteristics. Indeed, the distribution of predators and prey and their interactions can be influenced by the trichomes on potato plants (Lucas, 2005). Other factors may account for the choice of habitat by $H$. axyridis: abiotic ones such as landscape structure (Gardiner et al., 2009), insolation and humidity (Honěk, 1985), quantity and quality of host plants (Alhmedi et al., 2009), aphid species and their abundance (Wright \& Laing, 1980; Honěk, 1982; Thalji, 2006) and adjacent habitats (Colignon et al., 2001; Alhmedi et al., 2009).

In this study the species of aphids on the different crops were not the same. There were four species on wheat and broad bean, five and eight on corn and potato, respectively (Table 5). Nevertheless, it is not possible to draw any conclusions about the influence of these differences on the habitat preferences of $H$. axyridis as in our study and that of Alhmedi et al. (2007) no H. axyridis were recorded on wheat, a crop heavily infested with aphids whereas $H$. axyridis colonizes and reproduces in potato crops that are not infested with aphids (Nault \& Kennedy, 2003). Other studies record $H$. axyridis in the same crops as we studied but at lower densities: $0.02,0.03$ and 0.01 individuals per $\mathrm{m}^{2}$ in wheat, potato and corn crops, respectively (Nault \& Kennedy, 2003).

Recording the numbers of $H$. axyridis over long periods of time is of interest if we want to confirm that this species is continuing to increase in abundance. Studies on

TABLE 5. Aphid species diversity recorded in the four crops sampled.

\begin{tabular}{|c|c|c|c|c|}
\hline & Wheat & Corn & Potato & $\begin{array}{c}\text { Broad } \\
\text { bean }\end{array}$ \\
\hline Acyrthosiphon pisum Harris & & & $X$ & $X$ \\
\hline Aphis craccivora Koch & & & $X$ & \\
\hline Aphis fabae Scopoli & $\mathrm{X}$ & $\mathrm{X}$ & $\mathrm{X}$ & $\mathrm{X}$ \\
\hline Aphis frangulae Kaltenbach & & & $X$ & \\
\hline Aphis nasturtii Kaltenbach & & & $X$ & \\
\hline Macrosiphum euphorbiae Thomas & & & $\mathrm{X}$ & \\
\hline Megoura viciae Buckton & & & $\mathrm{X}$ & $\mathrm{X}$ \\
\hline Metopolophium dirhodum Walker & $\mathrm{X}$ & $X$ & & $\mathrm{X}$ \\
\hline Myzus persicae Sulzer & & & $X$ & \\
\hline Rhopalosiphum maidis Fitch & & $\mathrm{X}$ & & \\
\hline Rhopalosiphum padi L. & & $\mathrm{X}$ & & \\
\hline Sitobion avenae Fabricius & $X$ & & & \\
\hline Sitobion fragariae Walker & $\mathrm{X}$ & $\mathrm{X}$ & & \\
\hline
\end{tabular}


habitats other than crops indicate that since 2001 the numbers of $H$. axyridis in Belgium have increased (Adriaens et al., 2008). The variations in annual abundance of larvae in corn crops revealed by the ANCOVA analysis seem to be firstly linked to aphid abundance: larval numbers reflect number of eggs laid, which could reflect aphid abundance when adults are present early in the year. Secondly, larval abundance could also be due to a natural increase in the number of individuals in the landscape with continuing reproduction from year to year. Annual changes in $H$. axyridis abundance are also recorded in field crops in Quebec, where the percentage of $H$. axyridis was $55.4 \%$ in 2002 and $16.7 \%$ in 2003 (Lucas et al., 2007) and absent in potato crops in 2006, which followed a year when this species was abundant on this crop.

Regarding the phenology of the occurrence of adults of $H$. axyridis in corn and broad bean crops there are two peaks in abundance between their arrival in June and departure in September. The first peak consists of individuals that emerged from overwintering sites and were searching for food. The second peak consists of individuals that are the offspring of the overwintering adults. That is in the crops sampled $H$. axyridis only completed a single generation per year. However, in Europe, H. axyridis is known to be multivoltine, with two generations per year in Great Britain (Brown et al., 2008b) and France (Ongagna et al., 1993) and up to four generations in Greece (Katsoyannos et al., 1997). It is likely that Belgian $H$. axyridis are bivoltine as there are two peaks in the abundance of larvae, one in July and one in October (Adriaens et al., 2008). The second peak in the numbers of larvae is not recorded in field crops because their growing season only lasts until September.

The first peak in the numbers of larvae occurred 21 days after the aphid population peaked. That is, the numbers of $H$. axyridis were not synchronised with aphid abundance, as previously reported by Jansen \& Hautier (2008) in potato crops. H. axyridis larvae are able to reach the adult stage in the absence of aphids by feeding on alternative prey. The alternative food can be pollen (Berkvens et al., 2008) or other aphidophagous predators such as Coccinella septempunctata, Adalia bipunctata, Propylea quatuordecimpunctata or Episyrphus balteatus (Phoofolo \& Obrycki, 1998; Wells et al., 2010; Hautier et al., 2011; Ingels \& De Clercq, 2011). We observed $H$. axyridis feeding on syrphid and coccinellid pupae, and Colorado beetle larvae in potato crops. Indeed, other aphidophagous predators, such as $C$. septempunctata, $P$. quatuordecimpunctata, larvae of $E$. balteatus and Chrysopa carnea, were more abundant in most crops and most years than $H$. axyridis.

$H$. axyridis adults arrived in and left broad bean crops earlier than corn crops. The difference in its phenology in these two crops might be due, among other aspects, to differences in the phenology of these two crops and characteristics of the surrounding environment (Colignon et al., 2001; Alhmedi et al., 2009). It is likely that the $H$. axyridis adults that leave broad bean early (20/7) colonize other crops such as corn. Indeed, $H$. axyridis is a good flyer (Hodek et al., 1993), with a high dispersal capacity (With et al., 2002).

Logistic and Gompertz curves adequately describe the changes in the numbers of aphids and aphidophagous predators in corn and broad bean crops. These equations are based on the Pearl-Verhulst logistic equation, widely used to model density dependent population growth (Matis et al., 2009). Despite the fact that the RSS value of the fit of the Gompertz model to the numbers of adult $H$. axyridis on broad bean and of larvae on corn was lower than the value for the logistic model we used the latter for two reasons: (1) the RSS values of the fit of the logistic model were not different from those of the Gompertz model and (2) the rapid decrease in aphid abundance implies a rapid increase in the abundance predatory larvae. This growth trajectory corresponds to a symmetric population characterised by logistic curves.

$H$. axyridis abundance and phenology in the field crops sampled reveal that (1) H. axyridis is able to complete its development in corn and broad bean crops; (2) its phenology in corn and in broad bean crops differ and it is likely this is due to several factors including crop phenology and nature of the surrounding habitats; (3) larvae of $H$. axyridis can complete their development even when aphids are scarce, which indicates its larvae are able to feed on alternative prey such as other aphidophagous predators or pollen. This study appears to strengthen the hypothesis that $H$. axyridis can also inhabit field crops.

ACKNOWLEDGEMENTS. We thank V. Sibret and A.M. Buset for their technical assistance and D. Durieux for her helpful comments on previous versions of the manuscript. The authors are grateful to B. Bodson and F. Vancutsem of the "Unité de Phytotechnie des Régions Tempérées" (ULg, GxABT) for allowing us to sample the fields included in this study. This research was funded by the "Service Public de Wallonie" (SPW-DGO3, project n D31-1197 and D31-1247).

\section{REFERENCES}

Adriaens T., Gomez G.M.Y. \& Maes D. 2008: Invasion history, habitat preferences and phenology of the invasive ladybird Harmonia axyridis in Belgium. - BioControl 53: 69-88.

Alhmedi A., Haubruge E., Bodson B. \& Francis F. 2007: Aphidophagous guilds on nettle (Urtica dioica) strips close to fields of green pea, rape and wheat. - Insect Sci. 14: 419-424.

Alhmedi A., Haubruge E. \& Francis F. 2009: Effect of stinging nettle habitats on aphidophagous predators and parasitoids in wheat and green pea fields with special attention to the invader Harmonia axyridis Pallas (Coleoptera: Coccinellidae). - Entomol. Sci. 12: 349-358.

Berkvens N., Bonte J., Berkvens D., Deforce K., Tirry L. \& De Clerce P. 2008: Pollen as an alternative food for Harmonia axyridis. - BioControl 53: 201-210.

BRown M.W. 2003: Intraguild responses of aphid predators on apple to the invasion of an exotic species, Harmonia axyridis. — BioControl 48: 141-153.

Brown M.W. \& Miller S.S. 1998: Coccinellidae (Coleoptera) in apple orchards of eastern West Virginia and the impact of invasion by Harmonia axyridis. - Entomol. News 109: 143-151. 
Brown P.M.J., Adriaens T., Bathon H., Cuppen J., Goldarazena A., Hagg T., Kenis M., Klausnitzer B.E.M., Kovar I., Loomans A.J.M., Majerus M.E.N., Nedvěd O., Pedersen J., Rabitsch W., Roy H.E., Ternois V., Zakharov I.A. \& Roy D.B. 2008a: Harmonia axyridis in Europe: spread and distribution of a non-native coccinellid. - BioControl 53: 5-21.

Brown P.M.J., Roy H.E., Rothery P., Roy D.B., Ware R.L. \& MAJERUS M.E.N. 2008b: Harmonia axyridis in Great Britain: analysis of the spread and distribution of a non-native coccinellid. - BioControl 53: 55-67.

Brown P.M.J., Thomas C.E., Lombaert E., JefFries D.L., Estoup A. \& Handley L.-J.L. 2011: The global spread of Harmonia axyridis (Coleoptera: Coccinellidae): distribution, dispersal and routes of invasion. - BioControl 56: 623-641.

Buntin G.D. \& Bouton J.H. 1997: Aphid (Homoptera: Aphididae) management in alfalfa by spring grazing with cattle. J. Entomol. Sci. 32: 332-341.

Burgio G., Lanzoni A., Accinelli G. \& Maini S. 2008: Estimation of mortality by entomophages on exotic Harmonia axyridis versus native Adalia bipunctata in semi-field conditions in northern Italy. - BioControl 53: 277-287.

Colignon P., Hastir P., Gaspar C. \& Francis F. 2001: Effets de l'environnement proche sur la biodiversité entomologique en cultures maraichères de plein champ. - Parasitica 56: $59-70$.

Colunga-Garcia M. \& Gage S.H. 1998: Arrival, establishment, and habitat use of the multicolored Asian lady beetle (Coleoptera: Coccinellidae) in a Michigan landscape. - Environ. Entomol. 27: 1574-1580.

Darmani Kuhi H., Kebreab E., Lopez S. \& France J. 2003: A comparative evaluation of functions for the analysis of growth in male broilers. - J. Agric. Sci. 140: 451-459.

Debouche C. 1979: Présentation coordonée de différents modèles de croissance. - Rev. Statist. Appl. 27(4): 5-22.

Evans E.W. \& Gunther D.I. 2005: The link between food and reproduction in aphidophagous predators: a case study with Harmonia axyridis (Coleoptera: Coccinellidae). — Eur. J. Entomol. 102: 423-430.

FERran A. \& DiXon A.F.G. 1993: Foraging behavior of ladybird larvae (Coleoptera, Coccinellidae). — Eur. J. Entomol. 90: 383-402.

Gardiner M.M., Landis D.A., Gratton C., Schmidt N., O’Neal M., Mueller E., Chacon J., Heimpel G.E. \& DiFonzo C.D. 2009: Landscape composition influences patterns of native and exotic lady beetle abundance. - Divers. Distrib. 15: 554-564.

Hautier L., San Martin G., Callier P., de Biseau J.C. \& GréGOIRE J.C. 2011: Alkaloids provide evidence of intraguild predation on native coccinellids by Harmonia axyridis in the field. - Biol. Invasions 13: 1805-1814.

HodeK I. 1973: Biology of Coccinellidae. Dr W. Junk, The Hague, $260 \mathrm{pp}$.

Hodek I., Iperti G. \& Hodkova M. 1993: Long-distance fligths in coccinellidae (Coleoptera). - Eur. J. Entomol. 90: 403-414.

HoNĚK A. 1982: Factors which determine the composition of field communities of adult aphidophagous coccinellidae (Coleoptera) - J. Appl. Entomol. 94: 157-168.

HonĚK A. 1985: Habitat preferences of aphidophagous coccinellids (Coleoptera). - Entomophaga 30: 253-264.

Ingels B. \& De ClercQ P. 2011: Effect of size, extraguild prey and habitat complexity on intraguild interactions: a case study with the invasive ladybird Harmonia axyridis and the hoverfly Episyrphus balteatus. - BioControl 56: 871-882.
JANSEN J. \& HAUTIER L. 2008: Ladybird population dynamics in potato: comparison of native species with an invasive species, Harmonia axyridis. - Biol. Cont. Invas. 53: 223-233.

JANSEN J.P. \& WARNIER A.M. 2004: Aphid specific predators in potato in Belgium. - Commun. Agric. Appl. Biol. Sci. 69: 151-156.

Katsoyannos P., Kontodimas D.C., Stathas G.J. \& Tsartsalis C.T. 1997: Establishment of Harmonia axyridis on citrus and some data on its phenology in Greece. - Phytoparasitica 25: 183-191.

Kосн R.L. 2003: The multicolored Asian lady beetle, Harmonia axyridis: A review of its biology, uses in biological control, and non-target impacts. - J. Insect Sci. 3(32): 16 pp.

Koch R.L., Venette R.C. \& Hutchison W.D. 2006: Invasions by Harmonia axyridis (Pallas) (Coleoptera: Coccinellidae) in the Western hemisphere: implications for South America. Neotrop. Entomol. 35: 421-434.

LaMana M.L. \& Miller J.C. 1996: Field observations on Harmonia axyridis Pallas (Coleoptera: Coccinellidae) in Oregon. - Biol. Control 6: 232-237.

López S., France J., Gerrits W.J.J., Dhanoa M.S., Humphries D.J. \& DiJKstra J. 2000: A generalized Michaelis-Menten equation for the analysis of growth. - J. Anim. Sci. 78: $1816-1828$.

LUCAS E. 2005: Intraguild predation among aphidophagous predators. - Eur. J. Entomol. 102: 351-363.

Lucas E., Vincent C., Labrie G., Chouinard G., Fournier F., Pelletier F., Bostanian N.J., Coderre D., Mignault M.P. \& LAFONTAINE P. 2007: The multicolored Asian ladybeetle Harmonia axyridis (Coleoptera: Coccinellidae) in Quebec agroecosystems ten years after its arrival. - Eur. J. Entomol. 104: 737-743.

Matis J.H., Kiffe T.R., van der Werf W., Costamagna A.C., Matis T.I. \& Grant W.E. 2009: Population dynamics models based on cumulative density dependent feedback: A link to the logistic growth curve and a test for symmetry using aphid data. - Ecol. Model. 220: 1745-1751.

MCClure M.S. 1987: Potential of the Asian predator, Harmonia axyridis Pallas (Coleoptera, Coccinellidae), to control Matsucocus resinosae Bean and Godwin (Homoptera: Margarodidae) in the United-States. - Environ. Entomol. 16: 224-230.

Michaud J.P. 2002: Invasion of the Florida citrus ecosystem by Harmonia axyridis (Coleoptera: Coccinellidae) and asymmetric competition with a native species, Cycloneda sanguinea. - Environ. Entomol. 31: 827-835.

Michels G.J. \& Behle R.W. 1992: Evaluation of sampling methods for lady beetles (Coleoptera: Coccinellidae) in grainsorghum. - J. Econ. Entomol. 85: 2251-2257.

Musser F.R. \& Shelton A.M. 2003: Bt sweet corn and selective insecticides: impacts on pests and predators. - J. Econ. Entomol. 96: 71-80.

Nault B.A. \& Kennedy G.G. 2003: Establishment of multicolored Asian lady beetle in Eastern North Carolina: seasonal abundance and crop exploitation within an agricultural landscape. - BioControl 48: 363-378.

Ongagna P., Giuge L., Iperti G. \& Ferran A. 1993: Cycle de développement d'Harmonia axyridis (Col. Coccinellidae) dans son aire d'introduction: Le sud-est de la France. Entomophaga 38: 125-128.

OtTaRt N. 2005: L'impact de la coccinelle invasive Harmonia axyridis sur les populations de coccinelles indigènes à Bruxelles. Theis, Université Libre de Bruxelles, 84 pp.

Phoofolo M.W. \& OBRYCKI J.J. 1998: Potential for intraguild predation and competition among predatory Coccinellidae and Chrysopidae. - Entomol. Exp. Appl. 89: 47-55. 
Phoofolo M.W., Elliott N.C. \& Giles K.L. 2009: Analysis of growth and development in the final instar of three species of predatory Coccinellidae under varying prey availability. Entomol. Exp. Appl. 131: 264-277.

Roy H.E., Adriaens T., Isaac N.J.B., Kenis M., Onkelinx T., Martin G.S., Brown P.M.J., Hautier L., Poland R., Roy D.B., Comont R., Eschen R., Frost R., Zindel R., Van Vlaenderen J., Nedvěd O., Ravn H.P., Grégoire J.-C., De BisEAU J.-C. \& MAES D. 2012: Invasive alien predator causes rapid declines of native European ladybirds. - Divers. Distrib. 18: 717-725.

Sloggett J.J., OBRYCKi J.J. \& Haynes K.F. 2009: Identification and quantification of predation: novel use of gas chromatography-mass spectrometric analysis of prey alkaloid markers. - Funct. Ecol. 23: 416-426.

Snyder W.E., Clevenger G.M. \& Eigenbrode S.D. 2004: Intraguild predation and successful invasion by introduced ladybird beetles. - Oecologia 140: 559-565.

Tedders W.L. \& Schaefer P.W. 1994: Release and establishment of Harmonia axyridis (Coleoptera, Coccinellidae) in the Southeastern United-States. - Entomol. News 105: 228-243.

Tenhumberg B. \& Poenling H.M. 1995: Syrphids as natural enemies of cereal aphids in Germany: aspects of their biology and efficacy in different years and regions. - Agr. Ecosyst. Environ. 52: 39-43.

ThalJI R. 2006: Composition of coccinellid communities in sugar beet fields in Vojvodina. - Proc. Nat. Sci. Matica Srpska (Novi Sad) 110: 267-273.
Wells M.L. \& McPherson R.M. 1999: Population dynamics of three coccinellids in flue-cured tobacco and functional response of Hippodamia convergens (Coleoptera: Coccinellidae) feeding on tobacco aphids (Homoptera: Aphididae). Environ. Entomol. 28: 768-773.

Wells M.L., McPherson R.M., Ruberson J.R. \& Herzog G.A. 2001: Coccinellids in cotton: population response to pesticide application and feeding response to cotton aphids (Homoptera: Aphididae). - Environ. Entomol. 30: 785-793.

Wells P.M., Baverstock J., Majerus M.E.N., Jiggins F.M., Roy H. \& Pell J.K. 2010: Intraguild predation of non-coccinellid aphid natural enemies by Harmonia axyridis: prey range and factors influencing intraguild predation. - IOBC/WPRS Bull. 58: $185-192$.

WINSOR C.P. 1932: The Gompertz curve as a growth curve. Proc. Nat. Acad. Sci. U.S.A. 18: 1-8.

With K.A., Pavuk D.M., Worchuck J.L., OAtes R.K. \& Fisher J.L. 2002: Threshold effects of landscape structure on biological control in agroecosystems. - Ecol. Appl. 12: 52-65.

Wright E.J. \& LAING J.E. 1980: Numerical response of coccinellids to aphids in corn in Southern Ontario - Can. Entomol. 112: 977-988.

Zwietering M.H., Jongenburger I., Rombouts F.M. \& VAN't RIET K. 1990: Modeling of the bacterial growth curve. Appl. Environ. Microbiol. 56: 1875-1881.

Received June 26, 2012; revised and accepted November 22, 2012 